\title{
Pengaruh Pembangunan Infrastruktur Terhadap Kinerja Kepala Desa Bontomanai Kecematan Bungaya Kabupaten Gowa
}

\author{
The Effect of Infrastructure Development on the Performance of the Head of Bontomanai \\ Village, Bungaya District, Gowa
}

\author{
Muhammad Bakri $^{1 *}$, A. Iman Zulfikar ${ }^{1}$, Sumarni Sarong1, Baso R. ${ }^{2}$, Jainuddin ${ }^{3}$ \\ *Email: m.bakri933@gmail.com \\ ${ }^{1}$ Program Studi Manajemen, Sekolah Tinggi Ilmu Wira Bhakti Makassar \\ ${ }^{2}$ Program Studi Akuntansi, Sekolah Tinggi Ilmu Wira Bhakti Makassar \\ ${ }^{3}$ Program Studi Pendidikan Matematika, Fakultas Keguruan dan Ilmu Pendidikan, Universitas Bosowa
}

Diterima: 12 September 2021 / Disetujui: 24 Desember 2021

\begin{abstract}
ABSTRAK
Penelitian ini bertujuan untuk menguji pengaruh pembangunan infrastruktur terhadap kinerja kepala Desa Bontomanai Kecematan Bungaya Kabupaten Gowa. Pembangunan kadang menjadi tolak ukur suatu kepala pemerintah terhadap kinerjanya. Kepala desa dengan dana desa yang begitu besar sangat besar perlu dipertanyakn jika tidak ada pembangunan yang terjadai. Penelitian ini menggunakan data primer yaitu dengan menyediakan pertanyaan dalam bentuk kuesioner yang dibagikan kepada responden yang merupakan masyarakat yang tersebar dibeberapa dusun lingkup desa Bontomanai. Sampel dipilih dengan menggunakan metode purposive sampling. Responden dalam penelitian ini adalah Masyarakat di Desa Bontomanai. Sebanyak 97 kuesioner yang bagikan dan 97 kuesioner yang kembali. Data yang diperoleh kemudian diproses dan dianalisis 97 kuesioner. Metode statistik yang digunakan untuk menguji hipotesis adalah analisis regresi linear sederhana. Hasil penelitian ini menunjukkan bahwa pembangunan infrastruktur berpengaruh terhadap kinerja kepala Desa Bontomanai.
\end{abstract}

Kata Kunci: Infrastruktur, Kinerja, Kepala Desa

\section{ABSTRACT}

This study aims to examine the effect of infrastructure development on the performance of the head of Bontomanai Village, Bungaya District, Gowa Regency. Development is sometimes a measure of a head of government's performance. The village head with such large village funds needs to be questioned if no development occurs. This study uses primary data, namely by providing questions in the form of a questionnaire which is distributed to respondents who are people who are scattered in several hamlets within the scope of Bontomanai village. Samples were selected using purposive sampling method. Respondents in this study were people in Bontomanai Village. A total of 97 questionnaires were distributed and 97 were returned. The data obtained were then processed and analyzed by 97 questionnaires. The statistical method used to test the hypothesis is simple linear regression analysis. The results of this study indicate that infrastructure development affects the performance of the head of Bontomanai Village.

Keywords: Infrastructure, Performance, Village Head

(c) ()

\section{A. PENDAHULUAN}

Undang-undang Nomor 32 Tahun 2004, mengamanatkan bahwa semakin menguatkan posisi daerah dalam upaya meningkatkan kemampuan di segala bidang terutama Kabupaten dan Kota sebagai titik berat otonomi daerah. Dalam kerangka otonomi daerah, salah satu komponen yang 
masih perlu dikembangkan adalah wilayah pedesaan. Undang-Undang Nomor 6 Tahun 2014 Tentang Desa yang mengamanatkan pada pasal 1 ayat (3) menyebutkan bahwa "Pemerintah desa adalah Kepala Desa atau yang disebut dengan nama lain dibantu perangkat desa sebagai unsur penyelenggaraan pemerintah desa". Selanjutnya pada pasal 26 ayat (1), Kepala Desa bertugas menyelenggarakan pemerintah desa, melaksanakan pembangunan desa, pembinaan kemasyarakatan desa dan pemberdayaan masyarakat desa. Jelas dikatakan dalam hal ini bahwa kepala desa memiliki tugas dan kewajiban tidak hanya menyelenggarakan urusan pemerintahan tapi juga pembangunan.

Kepala desa sebagai bagian dari aparat desa dituntut untuk dapat menjadi motor penggerak dalam memimpin pembangunan desa karena aparat desa bersentuhan langsung dengan masyarakat sehingga akan lebih memahami keadaan dan kondisi masyarakat. Dari penjelasan tersebut dapat dikatakan bahwa kesempurnaan kinerja Kepala Kesa berpengaruh besar dalam kesempurnaan serta kualitas aparatur desa sehingga berperan penting pada suatu situasi keadaan Desa Bontomanai baik pada kesejahteraan masyarakat dan kemajuan desa yang di harapkan masyarakat Desa Bontomanai Kecamatan Bungaya.

Banyak individu-individu dalam organisasi pemerintah yang menafsirkan keluhan dari masyarakat terhadap mutu pelayanan yang diberikan adalah suatu peluang untuk memperbaiki keadaan dari yang kurang sempurna menjadi sempurna. (Ardhiansyah, Suntoro, \& Nurmalisa, 2017). Pelaksanaan otonomi daerah, secara empiris membawa perubahan dan inovasi dari sistem penyelenggaraan pemerintah desa yang merupakan ujung tombak pemerintahan yang berfungsi sebagai pengayom, pelayan dan pembina.

Pembangunan terhadap Infrasruktur desa terkadang terjadi masalah yang muncul dalam pelaksanaan proses pengelolaan pembangunan infrastruktur desa yaitu kondisi desa yang belum mampu melepaskan diri dari ketergantungan bantuan pemerintah pusat dan daerah. Perubahan kondisi fisik desa lambat dilakukan karena desa terletak agak jauh dari pertumbuhan Kota keterbatasan anggaran pemerintah desa untuk melakukan proses pembangunan fasilitas tertentu membuat desa tidak dapat berbuat banyak melakukan pembangunan infrastruktur desa karena jumlah anggaran dana desa yang paling menentukan pembangunan infrastruktur desa yang akan dibangun. 
Permasalahan, kendala ataupun halangan dalam membangun infrastruktur desa kiranya menjadi pelajaran berharga untuk dievaluasi dengan dasar agar dapat dijadikan bahan koreksi pembangunan infrastruktur desa kedepan.

Tugas dan fungsi Kepala Desa secara terperinci termuat dalam Undang-Undang tentang Desa Nomor 6 Tahun 2014. Selanjutnya dalam melaksanakan tugas sebagaimana dimaksud pada ayat (1), Kepala Desa berhak: a. mengusulkan struktur organisasi dan tata kerja Pemerintah Desa; b. mengajukan rancangan dan menetapkan Peraturan Desa; c. menerima penghasilan tetap setiap bulan, tunjangan, dan penerimaan lainnya yang sah, serta mendapat jaminan kesehatan; d. mendapatkan pelindungan hukum atas kebijakan yang dilaksanakan; dan e. memberikan mandat pelaksanaan tugas dan kewajiban lainnya kepada perangkat Desa.

Pemerintah Desa tersusun didalam suatu organisasi. Organisasi itu harusnya sederhana dan efektif. Hal itu perlu diperhatikan, meningat kenyataan bahwa di Desa tidak ada lagi instansi sektoral atau instansi vertikal. Jumlah pemuka masyarakat juga amat terbatas jumlahnya. Sederhana antara lain berarti mudah disesuaikan dengan kebutuhan dan kondisi setempat.
Penelitian ini bertujuan untuk menguji pengaruh pembangunan infrastruktur terhadap kinerja kepala Desa Bontomanai Kecematan Bungaya Kabupaten Gowa. Pembangunan kadang menjadi tolak ukur suatu kepala pemerintah terhadap kinerjanya. Kepala desa dengan dana desa yang begitu besar sangat besar perlu dipertanyakn jika tidak ada pembangunan yang terjadai.

\section{B. METODE PENELITIAN}

\section{a. Lokasi dan Waktu Penelitian}

Lokasi penelitian ini dilakukan di Desa Bontomanai Kecamatan Bungaya Kabupaten Gowa Provinsi Sulawesi Selatan. Waktu penelitian tahun 2021.

\section{b. Jenis Penelitian}

Penelitian ini menggunakan metode penelitian kuantitatif deskriptif.

\section{c. Populasi dan Sampel}

Sedangkan teknik pengambilan sampel dalam penelitian ini adalah Proportionate straitified random sampling yaitu teknik pengambilan sampel yang digunakan apabila populasi mempunyai anggota yang tidak homogen dan berstrata secara proporsional yaitu responden diambil dari perwakilan dusun di Desa Bontomanai. Dengan menggunakan rumus sampel kelompok (Sugiyono, 2018): 


$$
n i=\frac{N i}{N} \times n
$$

ni = Banyaknya Sampel pada Strata

$\mathrm{Ni}=$ Banyaknya Populasi pada Strata

$\mathrm{N}=$ Banyaknya Populasi Keseluruhan

$\mathrm{n}=$ Banyaknya Sampel Keseluruhan

\section{d. Teknik Pengumpulan Data}

\section{a. Kuisioner}

Menurut Sugiyono, (2018) Kuesioner adalah salah satu teknik pengumpulan data yang dilakukan dengan cara memberikan beberapa pertanyaan maupun pertanyaan secara tertulis kepada responden. Dalam pelaksanaannya, terjun langsung ke lapangan perlu dilakukan untuk mendapatkan data yang diinginkan karena melalui metode ini memerlukan kontak langsung antara responden dengan peneliti. Kuesioner yang disebarkan berfokus pada masyarakat di Desa Bontomanai.

b. Dokumentasi

Dokumentasi adalah teknik pengumpulan data melalui peninggalan tertulis, seperti Peraturan Desa, RPJMDes, Laporan Pertanggungjawaban Kinerja, Laporan Akuntabilitas Kinerja, berbagai arsip maupun dokumen dari pihak terkait, buku-buku ilmiah, jurnal atau dokumen lain yang diperoleh yang berhubungan dengan yang akan diamati.

\section{e. Metode Analisis}

a. Pengolahan Data

Pengolahan data adalah kegiatan lanjutan setelah pengumpulan data dilaksanakan. Pengolahan data meliputi memeriksa (editing), proses pemberian identitas (coding), pemberian nilai (scoring) dan proses pembeberan (tabulation).

Editing yaitu memeriksa kembali data yang telah masuk ke responden mana yang relevan. Editing data merupakan proses pengoreksian dan pengecekan terhadap angket yang telah dijawab oleh responden apakah sudah dijawab secara lengkap atau belum. Seandainya sudah dijawab apakah sudah benar. Seandainya ada angket yang rusak, maka angket tersebut harus disortir dan tidak di proses lebih lanjut dalam tahap pengolahan data.

Coding yaitu pemberian data, simbol atau kode bagi tiap-tiap data yang termasuk dalam kategori yang sama. Maksudnya adalah angket yang telah diedit diberi identitas sehingga memiliki arti dapat diproses pada tiap pengolahan data lebih lanjut. Dalam penelitian ini, untuk memudahkan dalam mengolah data, nama responden di imput berdasarkan nomor urut jumlah sampel.

Scoring yaitu memberi angka pada lembar jawaban angket tiap subjek score dari tiap item atau pertanyaannya pada angket ditentukan sesuai dengan perangkat pilihan (option). Pada tahap ini, kuesioner yang telah diisi oleh responden dengan menggunakan tanda check list, ketika 
diimput diubah menjadi angka untuk kemudian dapat dihitung berapa persentase dan juga frekuensinya.

Tabulasi yaitu memasukan data pada table-tabel tertentu dan mengatur angkaangka serta menghitungnya. Pembuatan table dan memasukan data hasil angket kedalamnya sebagai persiapan analisis data melalui penerapan rumus statistic yang dipilih. Dalam penelitian ini table yang di gunakan yaitu frekuensi (F) dan juga persentase $(\%)$.

\section{b. Analisis Data}

Untuk menganalisis data yang telah terkumpul dari hasil penelitian yang bersifat kuantitatif, maka penulis menggunakan analisis statistic yaitu distribusi frekuensi dengan menggunakan aplikasi computer SPSS 20 for windows dan skala pengukuran Likert digunakan untuk mengukur sikap, pendapat, dan persepsi seseorang tentang fenomena sosial dalam penelitian, fenomena sosial ini, telah ditetapkan secara spesifik oleh peneliti yang selanjutnya disebut sebagai variabel penelitian (Sugiyono, 2015). Berikut ini merupakan tabel jawaban dari setiap item pertanyaan yang menggunakan skala likert:

\begin{tabular}{lc}
\hline Skala Jawaban & Nilai \\
\hline Sangat Setuju (SS) & 5 \\
Setuju (S) & 4 \\
Netral (N) & 3 \\
Tidak Setuju (TS) & 2 \\
Sangat Tidak Setuju (STS) & 1 \\
\hline
\end{tabular}

\section{HASIL DAN PEMBAHASAN}

\section{Gambaran Umum Responden}

Dalam melakukan penelitian ini penulis menyebar kuisioner kepada warga masyarakat dan pengembangan SDM Kab. Bulukumba kuisioner ini terdiri atas 2 bagian, yaitu itu yang pertama adalah pembangunan infrastruktur dan yang kedua kinerja kepala desa.

Untuk mendapatkan gambaran mengenai masyarakat yang menjadi responden dalam penelitian ini, berikut akan diuraikan pengelompokan masyarakat menurut usia, jenis kelamin, pendidikan, asal dusun.

Tabel 1. Data Responden Menurut Usia

\begin{tabular}{clcc}
\hline No & $\begin{array}{l}\text { Usia } \\
\text { Responden }\end{array}$ & Jumlah & Persentanse (\%) \\
\hline 1 & $17-24$ tahun & 37 & 38.14 \\
2 & $30-34$ tahun & 21 & 21.65 \\
3 & $35-39$ tahun & 8 & 12 \\
4 & $40-44$ tahun & 12 & 8 \\
5 & $45-49$ tahun & 16 & 6 \\
6 & $51-55$ tahun & 3 & 32 \\
\hline & Total & 97 & $100 \%$ \\
\hline
\end{tabular}

Sumber data diolah, 2021

Berdasarkan Tabel di atas dari 97 orang responden yang menjadi objek Penelitian 37 orang adalah berusia 17-24 tahun $(38,14 \%), 21$ orang adalah Berusia 30-34 tahun ( $21,65 \%) 8$ orang adalah berusia 35-39 tahun (12\%) 12 orang adalah berusia 40-44 tahun ( $8 \%$ ) 16 orang adalah berusia 45-49 tahun (6\%) 3 orang adalah berusia 51-55 tahun (32\%). 
Tabel 2. Data Responden Jenis Kelamin

\begin{tabular}{|c|c|c|c|}
\hline No & Uraian & Jumlah & Persentanse (\%) \\
\hline 1 & Laki-laki & 52 & 53,60 \\
\hline 2 & Perempuan & 45 & 46,39 \\
\hline & Jumlah & 97 & $100 \%$ \\
\hline
\end{tabular}

Berdasarkan Tabel 2. di atas menunjukkan bahwa responden yang berjenis kelamin laki-laki sebesar 52 orang atau $53,60 \%$ dan responden yang berjenis kelamin perempuan 45 orang atau 46,39\%. Berdasarkan tabel di atas dari 97 orang yang menjadi objek penelitian 13 orang responden dalam satu dusun $(13,40 \%) 15$ orang responden dalam satu dusun $(15,46)$ 12 orang responden dalam satu dusun $(12,37) 13$ orang responden dalam satu dusun $(13,40) 14$ orang responden dalam satu dusun $(14,43) 11$ orang responden dalam satu dusun $(11,34) 7$ orang responden dalam satu dusun $(7,22) 12$ orang responden dalam satu dusun $(12,37)$

Tabel 3. Data Responden Menurut Pendidikan

\begin{tabular}{llcc}
\hline No & Uraian & Jumlah & Persentanse (\%) \\
\hline 1 & SD & 29 & 29,90 \\
2 & SMP & 14 & 14,43 \\
3 & SMA & 40 & 41,24 \\
4 & S1 & 14 & 14,43 \\
\hline & Total & 97 & $100 \%$ \\
\hline
\end{tabular}

Sumber : Data diolah, 2021

Berdasarkan Tabel 3., di atas dari 97 orang terdapat 29 orang atau (29,90) orang yang berpendidikan SD, 14 orang atau ( 14,43 ) orang yang berpendidikan SMP, 40 orang atau $(41,24)$ orang yang berpendidikan SMA, 14 orang atau $(14,43)$ orang yang berpendidikan S1.

\section{Uji Kualitas Data}

a. Uji Validitas (Test Of Validity)

Validitas mempunyai arti sejauh mana ketepatan dan kecermatan suatu alat ukur (dalam hal ini kuisioner) melakukan fungsi ukurnya. Pengujian validitas dalam penelitian ini dilakukan dengan korelasi pearsen validitas dengan tehnik produk moment yaitu scortiatition dikelorelasikan dengan scor total. Uji vadilitas ini mengunakan paket program SPSS for windows versi 26 dengan hasil sebagai berikut

Tabel 4. Rekapitulasi Hasil Uji Validitas

\begin{tabular}{llcl}
\hline No & Variabel & $\mathrm{r}_{\text {hitung }}$ & Keterangan \\
\hline \multicolumn{3}{l}{ Pembangunan Infrasturktur $(\mathrm{X})$} \\
\hline 1 & X1.1 & 0.621 & Valid \\
2 & X1.2 & 0,718 & Valid \\
3 & X1.3 & 0,734 & Valid \\
4 & X1.4 & 0,712 & Valid \\
5 & X1.5 & 0,841 & Valid \\
6 & X1.6 & 0,841 & Valid \\
7 & X1.7 & 0,867 & Valid \\
8 & X1.8 & 0,674 & Valid \\
9 & X1.9 & 0,809 & Valid \\
10 & X1.10 & 0,639 & Valid
\end{tabular}

Dari kesepuluh pernyataan dalam variabel gaya kepemimpinan bahwa ke sepuluh butir pernyataan memiiki nilai hasil lebih dari dari nilai 0.3. Berarti indikator yang digunakan dalam variabel penelitian ini layak atau valid digunakan sebagai pengumpulan data.

Tabel 5. Rekapitulasi Hasil Uji Validitas

\begin{tabular}{|c|c|c|c|}
\hline No & Variabel & $\mathrm{r}$ hitung & Keterangan \\
\hline \multicolumn{4}{|c|}{ Kinerja Kepala Desa (Y) } \\
\hline 1 & Y1.1 & 0,848 & Valid \\
\hline 2 & Y1.2 & 0,657 & Valid \\
\hline 3 & $\mathrm{X} 1.3$ & 0,663 & Valid \\
\hline 4 & $\mathrm{X} 1.4$ & 0,760 & Valid \\
\hline
\end{tabular}




\begin{tabular}{llrll}
5 & X1.5 & 0,706 & Valid & \\
6 & X1.6 & 0,630 & Valid & \\
7 & X1.7 & 0,691 & Valid & \\
8 & X1.8 & 0,652 & Valid & \\
9 & X1.9 & 0,614 & Valid & \\
10 & X1.10 & 0,655 & Valid & \\
\hline \multicolumn{5}{l}{ Sumber : Data diolah, 2021 } \\
\\
Dari kesepuluh & pernyataan dalam
\end{tabular}
variabel kinerja kepala Desa bahwa kesepuluh butir pernyataan memiliki nilai hasil lebih dari nilai 0,3 maka dapat $\mathrm{d}$ katakan pernyataan di atas adalah valid.

b. Uji Reliabilitas (Test Of Reliability)

Pengujian in dilakukan untuk menunjukkan sejauh mana suatu hasil pengukuran relative konsisten. Suatu pernyataan yang baik adalah pernyataan yang jelas mudah dipahami dan memiliki interpretasi yang sama meskipun disampaikan kepada responden yang berbeda dan waktu yang berlainan. Hasil pengujian reliabilitas adalah sebagai berikut:

Tabel 6. Rekapitulasi Hasil Uji Reabilitas

\begin{tabular}{|c|c|c|c|}
\hline Variabel & $\begin{array}{l}\text { Butir } \\
\text { Pertanyaan }\end{array}$ & Alpha & Keterangan \\
\hline $\begin{array}{l}\text { Pembang } \\
\text { unan } \\
\text { Infrastru } \\
\text { ktur (X) }\end{array}$ & 10 & 0,713 & 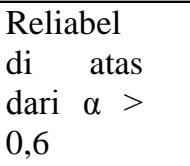 \\
\hline $\begin{array}{l}\text { Kinerja } \\
\text { Kepala } \\
\text { Desa } \\
\text { (Y) }\end{array}$ & 10 & 0,844 & $\begin{array}{l}\text { Reliabel } \\
\text { di atas } \\
\text { dari } \alpha> \\
0,6\end{array}$ \\
\hline
\end{tabular}

Berdasarkan Tabel 6 di atas variabel pembangunan infrastruktur nilai alpha sebesar $0,713>0,60$ dan pada variabel kinerja kepala desa nilai alpha sebesar 0,844 $>0,60$ sehingga dapat disimpulkan bahwa semua variabel yang digunakan dalam penelitian ini adalah reliabel karena memiliki nilai croambach Alpha $\alpha$ lebih besar dari 0,60.

\section{Uji Asumsi Klasik \\ a. Uji Normalitas Data}

Alat diagnosis yang digunakan dalam pengujian normaltas data adalah normal probability plot. Tujuannya menguji apakah sebuah model regresi, variabel dependenya maupun variabel independen memiliki distribusi normal maupun mendekati normal. Dari grafik uji normalitas terhadap model regresi dapat dilihat pada gambar berikut.

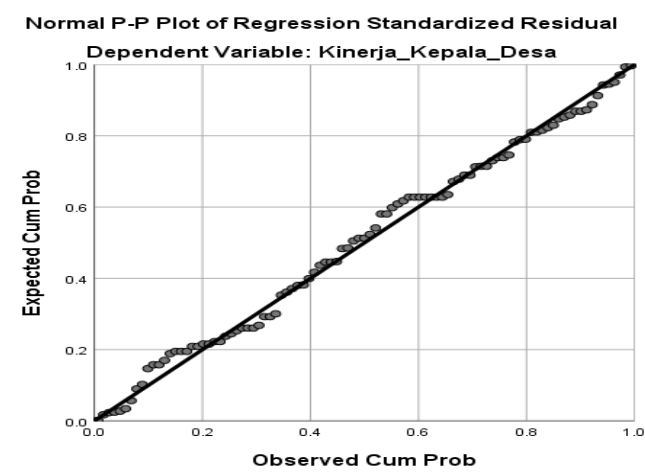

Gambar 1. Uji Normalitas

Berdasarkan gambar 1 terlihat bahwa titik menyebar di sekitar garis diagonal, serta penyebarannya mengikuti arah garis diagonal. Maka model regresi layak dipakai karena telah memenuhi asumsi normalitas. Artinya dapat diketahui adanya hubungan antara variabel $\mathrm{X}$ dan $\mathrm{Y}$ dimana model regresi normalits penyebaran datanya ratarata memenuhi di sekitar garis diagonal. 
b. Uji Heteroskedastisitas

Pengujian ini dilakukan untuk mengetahui apakah dalam sebuah model regresi terjadi ketidaksamaan samaan varian dari satu pengamatan yang lain. Prosedur dilakukan adalah mendeteksi dengan melihat $\mathrm{X}$ adalah $\mathrm{Y}$ yang telah diprediksi dan sumbu y adalah residual (Y prediksi -Y sesungguhnya) yang telah di student ship. Dasar pengambilan keputusan adalah sebagai berikut :

a. Jika ada pola tertentu, seperti titik titik (points) yang ada membentuk suatu pola tertentu yang teratur (bergelombang, melebar, kemudian menyempit), maka telah terjadi heteroskedastisitas

b. Jika tidak ada pola yang jelas titik titik menyebar di atas dan dibawah angka pada sumbu Y, maka tidak terjadi heteroskedastisitas.

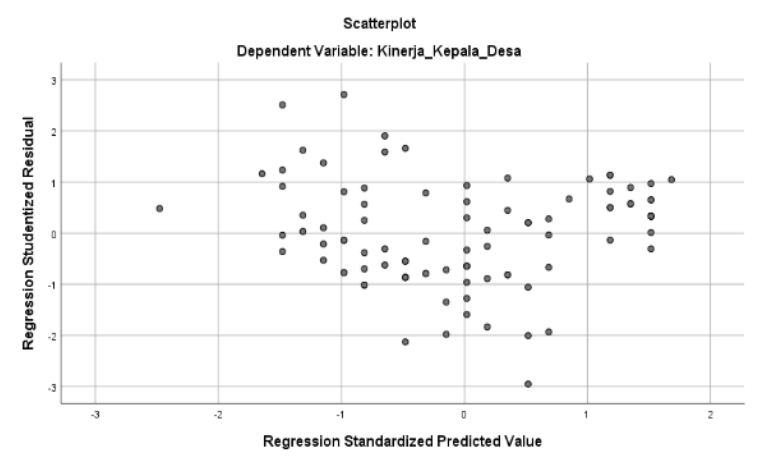

Gambar 2. Hasil uji heterokedastisitas

Hasil analisis dari grafik skater plots pada Gambar 2 terlihat titik - titik menyebar secara acak. Tidak membentuk suatu pola tertentu yang jelas, serta tersebar baik di atas maupun di bawah angka 0 pada sumbu Y. Hal ini berarti tidak terjadi heterokedastisitas pada model regresi.

\section{Metode Analisis Data}

a. Analisis Regresi Sederhana

Untuk mencari hubungan antara variabel bebas yaitu pembangunan infrastruktur $(\mathrm{X})$ terhadap variabel terikat yaitu kinerja kepala desa (Y) digunakan teknik analisis data regresi linier sederhana.

Tabel 7. Koefisien regresi tentang pengaruh Pembangunan infrastruktur $(\mathrm{X})$ terhadap Kinerja (Y)

\begin{tabular}{lllll}
\hline Variable & $\mathrm{B}$ & Std.Erorr & $\mathrm{t}$ & $\mathrm{Sig}$ \\
\hline Constant & 3.863 & 1.134 & 3.406 & .001 \\
Pembangunan & .040 & .033 & 1.206 & .002 \\
infratruktur & & & & \\
\hline Sumber : Data olahan SPSS 26, 2021
\end{tabular}

Berdasarkan hasil tersebut dapat diperoleh persamaan regresi linier sederhana sebagai berikut: $\mathrm{Y}=3.863+0,040 \mathrm{X}+\mathrm{e}$. Analisis atas hasil analisis tersebut dapat dinyatakan sebagai berikut:

\begin{tabular}{|c|c|c|c|c|}
\hline \multicolumn{5}{|c|}{ Model Summary } \\
\hline \multicolumn{2}{|c|}{ Model R } & R Square & $\begin{array}{l}\text { Adjusted } \\
\text { Square }\end{array}$ & $\begin{array}{l}\text { R Std. Error of the } \\
\text { Estimate }\end{array}$ \\
\hline 1 & $.123^{\mathrm{a}}$ & .015 & .005 & 1.93036 \\
\hline a. & \multicolumn{4}{|c|}{ Predictors: (Constant), Pembangunan_Infrastruktur } \\
\hline \multirow[t]{3}{*}{1.} & \multicolumn{2}{|c|}{ Konstanta } & sebesar & 3,863 \\
\hline & \multicolumn{4}{|c|}{ menunjukkan besarnya kinerja kepala } \\
\hline & desa & pada & saat & pembangunan \\
\hline
\end{tabular}

2. $\mathrm{b} 1=0,040$, artinya apabila variabel pembangunan infrastuktur sama dengan nol, maka meningkatnya variabel pembangunan infrasktruktur 
akan meningkatkan Kinerja Kepala Desa.

Berdasarkan hasil analisis yang bisa dilihat pada Tabel 7 diperoleh hasil koefisien determinasi berganda (R2 ) sebesar 0,15, hal ini berarti $15,0 \%$ perubahan kinerja Kepala Desa dipengaruhi oleh pembangunan infrastruktur. Sedangkan sisanya sebesar $85,0 \%$ disebabkan oleh faktor lain yang tidak termasuk dalam persamaan regresi yang dibuat

\section{b. Uji t ( t test)}

Pengujian ini dimaksudkan untuk mengetahui pengaruh masing-masing variabel independen terhadap variabel dependen. Caranya adalah dengan membandingkan nilai statistik thitung dengan nilai statistik ttabel dengan signifikan $(\alpha)$ yang digunakan yaitu $5 \%$. Masing-masing variabel bebas dikatakan mempunyai pengaruh yang signifikan (nyata) apabila probabilitas $<5 \%(\alpha)$. Hasil perhitungan uji $\mathrm{t}$ dengan menggunakan program SPSS for Windows versi 26 dapat dilihat pada Tabel 4.6. Berdasarkan tabel tersebut dapat diketahui besarnya pengaruh masing-masing variabel bebas terhadap variabel terikat sebagai berikut: Pengaruh variabel pembangunan infrastruktur (X) terhadap Kinerja Kepala Desa (Y) thitung untuk variabel pembangunan infrastruktur dimana probabilitas $<0,05$. Berarti
Pembangunan Infrastruktur (X) secara parsial mempunyai pengaruh signifikan terhadap Kinerja Kepala Desa (Y).

Setelah dilakukan pengujian statistik secara parsial (individu) dengan menggunakan uji t, maka analisis lebih lanjut dari hasil analisis regresi adalah Pengaruh pembangunan infrastruktur terhadap kinerja kepala Desa. Hasil uji regresi menunjukkan variabel pembangunan infrastruktur berpengaruh dan signifikan terhadap kinerja kepala desa dengan koefisien 0,15. Hal ini berarti dengan semakin baiknya pembangunan infrastruktur maka kinerja kepala Desa juga akan meningkat. Kinerja kepala desa akan terlihat pada terselenggaranya tugas dan fungsi di atas dengan baik, dalam arti ukurannya pada aspek kuantitas dan kualitas pekerjannya. Bernardian dalam Rahayu \& Lutfie, (2017). Berdasarkan tabel 6 bahwa koefisien korelasi pembangunan terhadap kinerja. Hal ini memberi arti bahwa hubungan antara pembangunan infrastruktur dengan kinerja kepala desa Bontomanai kecematan Bungaya Kabupaten Gowa adalah subtansial. Sedangkan determinasi (2) faktor ini mempunyai nilai sebesar 0,15 atau 15,0\%. Dengan memperhatikan tabel 6 di atas, secara parsial hipotesis alternative yang diajukan dapat diolah, yaitu variabel pembangunan infrastruktur mempunyai 
pengaruh signifikan terhadap kinerja kepala desa sedangkan arah hubungan variabel pembangunan infrastruktur ini dengan kinerja kepala Desa dan pengembangan SDM Kab. Gowa adalah positif. Kaplan dan Norton dalam (Ariesta, 2013) dengan menggunakan teknik Balanced Scorecard dalam menilai kinerja melalui empat perspektif yakni perspektif pelanggan, perspektif internal, perspektif inovasi, perspektif finansial. Dalam menilai kinerja kepala desa menurut hemat penulis sangat tepat.Manajemen kinerja memfokuskan pada apa yang diperlukan oleh organisasi, manajer, dan pekerja untuk berhasil (Wibowo, 2013).

\section{KESIMPULAN DAN SARAN}

Hasil penelitian dan pembahasan dapat ditarik kesimpulan bahwa pembangunan infrastruktur berpengaruh terhadap kinerja kepala desa. Hal ini berarti dengan semakin baik pembangunan infrastruktur maka kinerja kepala desa juga akan meningkat. Dari hasil pengukuran menunjukan bahwa pembangunan infrastruktur berpengaruh terhadap peningkatan kinerja Kepala Desa, hal ini kemungkinan disebabkan oleh beberapa lain hal, misalnya dari kapasitas aparatur pemerintahan desa atau dari peningkatan kapasitas Sumber Daya Manusia.

\section{DAFTAR PUSTAKA}

Amstrong, M., \& Barong, F. (2016). Manajemen Kinerja Cetakan Ketujuh. Jakarta: Erlangga.

Ardhiansyah, M., Suntoro, I., \& Nurmalisa, S. (2017). Persepsi masyarakat terhadap pelayanan publik oleh aparatur desa. Jurnal kultur demokrasi, 1-15.

Ariesta, F. (2013). Pengaruh Kualitas Sumberdaya Manusia, Pemanfaatan Teknologi Informasi, Dan Pengendalian Intern Akuntansi Terhadap Nilai Informasi Pelaporan Keuangan Pemerintah Daerah ( Studi pada Satuan Kerja Perangkat Daerah di Kabupaten Pasaman Barat). Jurnal Akuntansi, 1-17.

Burka, J. B., \& Yuen, L. M. (2018). Procrastination: Why You Do It, What to Do about It Now. Cambridge, MA: Da Capo Press.

Kotler, P., \& Keller, K. L. (2016). Marketing Management, 15th Edition. New Jersy: PrenticeHall Published.

Muin, I. (2013). Sosiologi Kurikulum. Jakarta: Erlangga.

Parsons, W. (2001). Public Policy: Pengantar Teori dan Praktik Analisis Kebijakan. Jakarta: Kencana Prenada Media Group.

Rahayu, A., \& Lutfie, H. (2017). Pengaruh Kualitas Layanan Dan Pelayanan Tambah Daya Terhadap Kepuasan Pelanggan Pt. Pln (Persero) Area Cijawura. eProceeding of Applied Science (pp. 399406). Jakarta: Universitas Telkom.

Soekanto, S. (2012). Sosiologi Suatu Pengantar. Jakarta: Rajawali Pers.

Sugiyono. (2018). Metode Penelitian Kuantitatif, Kualitatif, dan R\&D. Bandung: Alfabeta.

Syani, A. (2013). Sosiologi Skematika, Teori, dan Terapan. Jakarta: PT. Bumi Aksara.

Wibowo. (2013). Perilaku dalam Organisasi. Jakarta: PT. Raja Grafindo Persada. 